\title{
Interventions to Address \\ Discrimination against LGBTQi Persons
}

Zenobia Ismail and Topua Lesinko

University of Birmingham

3 June 2021

\section{Question}

What evidence is available on interventions to limit discrimination and abuse against people who are LGBTQi?

\section{Contents}

1. Summary

3. Annotated bibliography

The K4D helpdesk service provides brief summaries of current research, evidence, and lessons learned. Helpdesk reports are not rigorous or systematic reviews; they are intended to provide an introduction to the most important evidence related to a research question. They draw on a rapid desk-based review of published literature and consultation with subject specialists.

Helpdesk reports are commissioned by the UK Foreign, Commonwealth, and Development Office and other Government departments, but the views and opinions expressed do not necessarily reflect those of FCDO, the UK Government, K4D or any other contributing organisation. For further information, please contact helpdesk@k4d.info. 


\section{Summary}

There is very little literature on interventions and programmes that address discrimination against LGBTQi persons in the international development and international relations literature (Thiel , 2014). In general, development agencies have strong commitments to LGBTQi rights in their strategy and policy documents. However, they avoid addressing LGBTQi rights directly through programming. Historically, international donor support for LGBTQi rights has been channelled through health programmes (especially those related to sexual health or HIV/AIDS) and democracy and governance support programmes. Recently, there is a trend towards integrating LGBTQi rights across a broader set of development programmes under the auspices of "leave no one behind" (Haste, Overs \& Mills, 2016).

This annotated bibliography is based mainly on grey literature that describes the approach that various international development agencies have taken to address discrimination against LGBTQi persons. These reports use a variety of acronyms, such as LGBT, LGBTQ and LGBTI. Hence, a variety of acronyms are used in the review of the literature in this annotated bibliography.

Most of the programmes and interventions that are mentioned in the literature address LGBTQi rights by ensuring that men who have sex with men (MSM) and transgender people have access to healthcare that is funded by international aid. The other main conduit of support is to use aid funds to provide financial and technical support to organisations and activists who advocate for LGBTQi rights. However, some LGBTQi organisations lack capacity to apply for funding from international donors (Badgett et al., 2014). In some countries where there is very little or no protection for LGBTQi rights, advocacy organisations tend to support this issue through HIV/AIDS programmes or human rights.

Donor agencies have used international commitments to human rights as an entry point for dialogue on LGBTQi with other governments, in bilateral or multilateral engagement (Sida, n.d., Thiel, 2014). The United Nations (UN) has facilitated dialogue on the issue through its human rights platforms and all UN agencies have commitments to protecting LGBTQi rights in their strategies, policies or action plans. Many UN agencies have engaged in research or dialogue (United Nations, 2019). Some agencies have incorporated sexual orientation and identity into programmes on bullying in schools or HIV in prisons. The Swedish International Development Agency supports LGBTQi rights through its human rights approach to development (Nilsson, Lundholm \& Vagberg, 2013).

The literature highlights the following barriers that undermine the extent to which international development interventions or programmes can address discrimination against LGBTQi persons (UNDP, 2015, Haste et al., 2016):

- LGBTQi rights are still not viewed as a development priority and because they are controversial in some settings embassies are hesitant to engage with them;

- Limited data and understanding of the various issues that are categorised as LGBTQi curtails the extent to which these issues can be integrated with other development programmes; and

- Prejudice among staff at all levels in development agencies undermines their willingness to engage with LGBTQi rights and issues. 
The literature notes that lesbians and bisexual persons may still struggle to access healthcare as they do not benefit from initiatives that target MSM and transgender persons (Sida, n.d).

Disability was not discussed in the literature reviewed in this annotated bibliography.

\section{Annotated Bibliography}

USAID (n.d). LGBT Vision for Action: promoting and supporting the inclusion of lesbian, gay, bisexual, and transgender individuals. USAID.

https://www.usaid.gov/sites/default/files/documents/1861/LGBT_Vision_For_Action_May2014.pdf

USAID envisages a world in which the human rights of LGBT persons are respected so that they can live with dignity and be free from discrimination, persecution and violence. USAID will adopt the following principles to further this agenda: (1) account for country and cultural context, (2) ensure openness and safe space for dialogue, (3) integrate LGBT issues into USAID's work, (4) support and mobilise LGBT communities, and (5) build partnerships to create allies and champions. The aim of USAID is to protect human rights and empower LGBT persons as well as to increase the capacity of civil society organisations (CSOs) that focus on LGBT rights. USAID will become more inclusive in its development initiatives by ensuring that LGBT persons benefit from their programming.

The following approaches to more LGBT inclusive development work are discussed:

- Building attention to LGBT issues into operational policies and procedures: The USA Policy Framework, USAID Country Development Cooperative Strategy Guidance, USAID Project Design Guidance, USAID Automated Directive Systems, the USA Gender Equality and Family Empowerment Policy, USAID Strategy on Democracy and Human Rights and Governance, the US National Action Plan on Women, Peace and Security, USAID Global Health Strategic Framework, USAID Policy on Youth and Development and others incorporate the concerns of LGBT stakeholders to ensure that development objectives are inclusive.

- Integration: USAID field missions have developed LGBT inclusive Mission Orders which specify the responsibilities, processes and procedures for protecting and promoting the human rights of LGBT persons through mission operations and programming. LGBT rights may be enshrined in documents that focus exclusively on the issue, or they can be addressed along with broader issues relating to gender, diversity or disability.

- Sectoral programming: LGBT issues have been incorporated into health programming particularly with reference to HIV/AIDS and Democracy, Rights and Governance (DRG). HIV/AIDS programming targets populations at the highest risk including gay men and transgender persons. The inclusion of Men who have Sex with Men (MSM) as a priority population in national aid strategies and national planning bodies, even in countries which do not acknowledge the existence of MSM is a step towards furthering LGBT rights through aid funded programmes. The first interventions were developed in Asia and Latin America and more recently were integrated into programming in Africa. Support for transgender people has been transmitted through programming related to MSM. This USAID approach has been promoted by the President's Emergency Plan for Aids Relief 
(PEPFAR), the World Health Organisation and the United Nations Joint Programme on AIDS as international best practice.

LGBT issues have been addressed through DRG programmes. For example, in Colombia local government institutions and CSOs were supported in their efforts to establish inclusive rights. There were some achievements: (1) The Colombian National Police barred discrimination on the basis of sexual diversity or gender identity; (2) The Colombian Constitutional Court extended partnership benefits on inheritance and property rights to same sex couples and recognised effective civil unions. In Nicaragua USAID integrated DRG in its PEPFAR funded HIV/AIDS activities to address the health needs of MSM and transgender persons. In addition, training and finance was provided to strengthen institutions involved in advocacy for LGBT rights.

Support for research and learning: USAID has worked with UNDP to conducted ground-breaking research, such as the "Being LGBT In Asia" and "LGBT people in Europe and Eurasia region" research projects. These are multisectoral reports which were produced with grassroots LGBT organisations and community leaders to understand the challenges faced by LGBT persons in these regions. The reports document the discrimination faced by LGBT people, including exposure to violence, challenges with access to healthcare and other social services and discrimination in the workplace. The documents provide sectoral recommendations for entry points with respect to programming that is inclusive of LGBT people and CSOs.

USAID is involved in developing training material, tools and resources to further LGBT rights. This includes the first online course on LGBT rights, training at field missions and sector specific materials and resources that provide guidance on how to integrate LGBT issues across USAID programming. USAID will support local CSOs in country by providing them with tools and resources to strengthen their advocacy, strategic planning, financial management, internal governance processes, human resources and capacity to network with other local or regional bodies.

Sida. (n.d) Human rights of Lesbian, Gay, Bisexual and Transgender Persons: Conducting a Dialogue. Swedish International Development Cooperation Agency. https://publikationer.sida.se/contentassets/21013d2a0a3048ed8d3debd5de0a13d0/humanrights-of-lesbian-gay-bisexual-and-transgender-persons-conducting-a-dialogue_3327.pdf

In many countries there are LGBT organisations or loosely connected groups and networks which strive to fight for equal rights and opportunities for this community. They work through advocacy to alter the legal system so that the person's rights of LGBT individuals can be upheld. In addition, they provide social support and counselling. According to the Policy for Global Development in Sweden, the country is committed to tackling difficult and controversial issues such as the rights of LGBT persons. LGBT rights fit in with Sida's human rights-based approach to addressing poverty. The following human rights principles are relevant for protecting the rights of LGBT persons: transparency and good governance, accountability, legal norms and standards and non-discrimination.

There are number of pathways for raising the rights of LGBT persons. The United Nations Universal Periodic Review provides an opportunity to assess and discuss the rights of LGBT persons and to encourage human rights actors to provide information about discrimination 
towards LGBT persons. They are also entry points for establishing dialogue with governments, for example public health and discrimination. LGBT persons may struggle to access healthcare particularly in the context of HIV/AIDS. It is important for national health plans to report on access issues that pertain to MSM and transgender persons. Lesbian and bisexual woman are also marginalised with respect to access to healthcare. Dialogue with health ministries is an avenue to advocate for the inclusion of LGBT groups in National Health Plans and other national surveys. Discrimination against LGBT persons is an issue in a number of countries. Swedish embassies can work to encourage decriminalisation within the framework of ongoing human rights dialogue and legal reform programmes. Human rights arguments can be used to raise the need for legislation which protects LGBT individuals from discrimination including issues relating to hate speech and hate crime.

Thiel, M. (2014). LGBTQ politics and international relations: Here? Where? Used to it? International Politics Review. Vol 2. October.

https://link.springer.com/article/10.1057/ipr.2014.17

In general, there is a lack of literature on sexual rights and LGBTQ politics in the international relations literature. Sexual rights for LGBTQ individuals can be a point of contention which lead to culture wars or diplomatic rows. Advocacy on behalf of the LGBTQ community by Western countries or their international development agencies may lead to the politicisation of LGBTQ minority groups in some low- and-middle-income countries. In order to avoid or minimise a backlash, many donors have linked LGBTQ advocacy to international human rights issues. They evoke the universal validity of human rights conditions. Similarly, broader programmes on democratisation are an avenue for pursuing a global debate on sexual rights in non-Western countries. Support for LGBTQ communities can be provided through conduits such as advocacy for privacy rights, separation of state from religion, rule of law and human rights.

\section{Nilsson, A., Lundholm, K. and Vagberg, E. 2013. Study on Sida's work on human rights of Lesbian, Gay, Bisexual, Transgender and Intersex Persons. Sida.}

https://publikationer.sida.se/contentassets/d7abd0467e4742068d8650796e615d4d/15389.pdf

Sida commenced support for LGBTI persons in 2006 via the adoption of an Action Plan on Sexual Orientation and Gender Identity (2007- 2009). This led to a baseline study of interventions. Many Swedish embassies regarded LGBT rights as too difficult or a low priority compared with other issues. This report is an assessment of the results achieved so far. The report is based on information from the Sida Plus system and the CSO Project Database. Interviews were conducted with representatives at 33 Swedish embassies and 12 Swedish CSOs as well as with partners and staff at Sida headquarters.

The report finds that there was a growth in initiatives and programme budgets from 2006 to 2011 followed by stagnation. The report finds that Sida support for LGBTI persons has yielded the following positive results:

- Core funding from Sweden has helped key actors in the LGBTI global movement to work independently and proactively, and in some countries it has ensured the survival of organisations and protection of activists. In 2013 SIDA was supporting 11 LGBTI initiatives with a budget of 15.7 million Swedish Kroner. 
- There has been an increase in the mainstreaming of LGBTI issues across general programmes. More staff at Swedish CSOs are knowledgeable about these issues and have included LGBTI rights components in general programmes. LGBTI is now seen primarily as a human rights issue rather than an HIV/AIDS or health issue. Over 20 Swedish embassies report that LGBTI is part of their dialogue with other donors, governments and CSOs.

- Sweden has established a reputation as the leading donor for advocacy for LGBTI rights in development cooperation. Sida has practical knowledge on how to address LGBTI issues in different settings and at different levels. Other donors have approached Sida for technical support with respect to LGBTI rights.

Sida's achievements are attributed to high level political commitment by the Swedish government to addressing LGBTI rights. In addition, the combination of political dialogue, cultural events and organisational support has created a space for LGBTI organisations and activists to engage with mainstream human rights work. Sida is willing to listen to and support a locally defined agenda proposed by LGBTI activists in recipient countries.

A major challenge is that there needs to be better coordination of work targeting LGBTI rights. Progress has been achieved largely by the dedicated work of particular individuals in certain organisations, units and embassies. More attention must be devoted to lessons learned from the success factors and this should be shared with Swedish embassies and other donor organisations. Innovative ways to support grassroots LGBTI organisations in countries with weak systems and structures is necessary. Currently many of these small grassroots organisations are not in a position to access Sida funding. In cases where financial support has been phased out non-financial support should continue, for example in Vietnam.

Sida. (2014). The Rights of LGBTI People in Sub-Saharan Africa. Sida.

https://publikationer.sida.se/contentassets/89da6ee09a8547a7b876ce8c02e49aee/18254.pdf

LGBTI persons in Africa encounter many difficulties. In Uganda Evangelical pastors from the United States support conservative Ugandan politicians to purvey anti-LGBTI sentiments. This trend is spreading to other countries. In 2014, 36 African countries criminalised same-sex sexual acts, mainly through sodomy laws that were introduced during British colonial rule and survived independence. Although the law seldom mentions transgender persons they are often accused of homosexuality and are subject to arbitrary arrest. Some countries are unable to distinguish between homosexual and transgender persons, subjecting the latter to the same harsh penalties which are imposed on homosexuals. Few African countries are willing to make commitments to protect the human rights of LGBTI persons. Several African countries voted against United Nations (UN) resolutions which relate to sexual orientation and the rights of LGBTI persons. A notable exception is South Africa.

In countries where homosexuality is criminalised LGBTI organisations are generally not allowed to register. They may be some small, nascent organisations which encounter many challenges with respect to their growth and development. They sometimes work under the guise of HIV prevention or women's rights or human rights. The following questions relating to what Sweden can do to assist LGBTI persons in sub-Saharan Africa were raised: 
- Can Sweden be better updated on the legal and security situation facing LGBTI movements in the region?

- Can Sweden influence regional mechanisms that have potential to engage with sexual orientation and gender identity issues? For example, by raising LGBTI rights in a dialogue with regional human rights organisations and institutions or supporting the capacity development of national human rights institutions to enhance their interest in promoting the human rights of LGBTI people.

- Can Sweden offer more support to LGBTI actors and activists by supporting regional networking and capacity building for human rights and LGBTI organisations?

- Can Sweden offer more support to its embassies and consulates in the region to develop their capacity and interest in LGBTI rights?

- Can Sweden do more to include LGBTI organisations in social, cultural and professional events?

- Can more be done to include gender-based violence and LGBTI rights in ongoing regional programmes and in negotiations pertaining to new programmes targeting capacity building in the judiciary, police training or correctional services?

- Can more be done to highlight anti-discrimination codes of conduct and labour legislation with the aim of reducing discrimination based on sexual orientation?

- Can the inclusion of LGBTI persons in the sexual and reproductive health rights, HIV/AIDS and gender-based violence initiatives be enhanced?

- Can more be done to facilitate and support LGBTI reporting in the UN Universal Periodic Reviews, shadow reports and other UN or African Union statements?

USAID. (n.d). The multi-donor LGBTI Global Human Rights Initiative. USAID. https://www.usaid.gov/sites/default/files/documents/Final_Multi_Donor_LGBTI_Global_Human_R ights_Initiative_Overview_PARTNER_LOGOS.pdf

The multi-donor LGBTI Global Human Resource Rights Initiative (GHRI) is a five-year publicprivate partnership which leverages financial and technical resources from partners such as USAID, Swedish International Development Cooperation Agency, Global Affairs Canada, Astraea Lesbian Foundation for Justice, Equality Without Borders, the Williams Institute and the Franklin and Marshall College. The programme will run from 2019 to 2024 . The GHRI supports local initiatives to protect LGBTI people from violence, discrimination, stigma and criminalisation through research and data collection which can inform policy, social and behavioural change, communication efforts, country specific projects and emergency response. The project covers four regions: Africa, Asia, Europe and Eurasia, Latin America and the Caribbean. The GHRI has a programming component in focus countries where it helps local LGBTI groups with their interventions and strategies. The process is consultative and focuses on approaches which are most appropriate and least likely to inspire backlash. In addition, the GHRI provides urgent emergency support to LGBT groups that are under threat of violence, detention and arrest. It also provides medical, legal and relocation support. 
UNDP. (2015). Leave no one behind: Advancing Social, Economic, Cultural and Political Inclusion of LGBTI People in Asia and the Pacific - Summary. https://www.asia-

pacific.undp.org/content/rbap/en/home/library/democratic_governance/hiv_aids/leave-no-onebehind--advancing-social--economic--cultural-and-po.html

This report was prepared primarily for governments, policymakers, national human rights institutions, human rights defenders and community groups. The report provides data on linkages between LGBTI inclusion efforts and broader development or human rights agendas of bilateral and multilateral donors, development partners and the UN system. Overall, there is little mention of the role that international development partners play with respect to advancing LGBTI rights in the region.

HIV/AIDS has been used as an entry point for advocacy for LGBTI rights in Asia and the Pacific regions. LGBTI visibility is increasing in Asia and the Pacific region via community mobilisation and pride marches, festivals and through social media. LGBTI people are more visible in politics, the media and the private sector. These trends contribute to a more supportive environment for LGBTI people across the region. There have been some landmark developments in law and policy reform which are creating positive social environments for LGBTI people. This includes the decriminalisation of homosexuality and legal protection from discrimination due to sexual orientation or gender identity in some countries. There have been positive and progressive judicial decisions on the rights of transgender people in Hong Kong, India, Malaysia, Nepal and Pakistan. Many government agencies and parliaments are considering LGBT issues for the first time. However, there are still many challenges, including marginalisation of lesbians and bisexual people from access to healthcare. Violence towards LGBTI people continues. Homosexuality is still criminalised in several countries in Asia and the Pacific.

\section{Badgett, M.V.L., \& Sell, R. (2018). A Set of Proposed Indicators for the LGBTI Inclusion Index. New York. UNDP. https://openknowledge.worldbank.org/handle/10986/30994}

This document discusses a set of proposed indicators for a Global Index to measure the inclusion of LGBTI people. The inclusion of LGBTI people is necessary to deliver on the pledge of the 2030 Agenda for Sustainable Development to Leave No One Behind. The process of creating an LGBTI inclusion index started in 2015 when UNDP, in partnership with the Office of the High Commissioner for Human Rights, convened meetings with a multisectoral group of experts and representatives from civil society to discuss the development of such an index. The five dimensions of the index are: economic well-being, political and civil participation, education, health and personal security and violence. The purpose of the index can be summarised as follows: comparing the overall degree of inclusion across countries; assessing the progress towards inclusion over time within countries, regions and globally; establishing benchmarks for countries; and highlighting where resources are most needed. While such comparative data protection is necessary to highlight the plight of LGBTI people it must be considered that the data can be misused in some countries which argue for "curing" homosexuality rather than addressing issues of discrimination and cultural rejection of LGBTI persons. The document does not discuss how development agencies might use the index to inform programming decisions. 
Badgett, M. V. L., Nezhad, S., Waaldijk, K., \& van der Meulen Rogers, Y. (2014). The Relationship Between LGBT Inclusion and Economic Development: An analysis of Emerging Economies. USAID \& The Williams Institute.

https://williamsinstitute.law.ucla.edu/publications/lgbt-inclusion-economic-dev/

The study analyses this impact of social inclusion of LGBT people on economic development in 39 countries. The study builds on the capabilities approach and the concept of "freedoms" articulated by Amartya Sen. It also considers macrolevel approaches to inclusion such as the legal rights of LGBT people and assesses economic development in terms of per capita Gross Domestic Product (GDP) and the Human Development Index (HDI). Multivariate regression is used to analyse the effect of LGBT rights on economic development while controlling for other factors that also influence development.

The main findings of the study are as follows:

- Discrimination and violence towards LGBT people undermines their productive employment.

- Discrimination affects the physical and mental health of LGBT people which undermines the productivity in the workplace.

- LGBT students face discrimination in schools which leads to dropout and poorer prospects in the labour market.

- Regression analysis finds that one additional right on the Global Index on the Legal Recognition of Homosexual Orientation is associated with US $\$ 1,400$ more in per capita GDP plus a higher HDI value. The increase in GDP drops to US\$320 after other factors are controlled for. Although it is not possible to draw firm conclusions in the direction of the causal link with the macro analysis, the study concludes that overall there is a strong link between the rights of LGBT people and economic development.

Further research is needed to better understand the link between LGBT rights and development. However, the study strongly recommends that all areas of international development incorporate concerns about the rights of LGBT people. Moreover, it states that LGBT inclusion is relevant for development agency programming and the inclusion of LGBT people should be mainstreamed with development research in areas such as food policy, poverty alleviation, gender empowerment, democracy and governance, education, health, conflict situations, gender-based violence and other areas where LGBT people may be marginalised.

\section{Haste, P., Overs, C. \& Mills, E. (2016). Avenues for Donors to Promote Sexuality and Gender Justice. IDS Policy Briefing. Issue 120, June 2016. \\ https://opendocs.ids.ac.uk/opendocs/handle/20.500.12413/11640}

Until recently sexual and gender justice, including LGBT rights, were a low priority for international development actors. LGBT issues were historically situated within the international human rights focus of development agencies in the United States and Europe. Furthermore, HIV/AIDS programming was adapted to address LGBT issues, by ensuring that programmes catered for MSM and transgender woman. However, neither the health nor human rights approaches to LGBT rights considered wider issues of economic inequality faced by LGBT individuals. There has been a shift towards a broader approach to addressing the economic and social rights of LGBT persons. It is acknowledged that the conditions in which sexual and gender 
minorities work or study places them at a disadvantage which undermines the economic progress and stability of the countries in which they reside.

Sida, DFID (now FCDO) and the Canadian International development agency (CIDA), the Australian agency for International Development (AUS Aid) and USAID have integrated LGBT rights into their policy and strategy documents. Similarly large philanthropic organisations, such as the Open Society Foundation and the Bill and Melinda Gates Foundation, provide funds directly to LGBT organisations in countries where reforms are needed. United Nations organisations also fund programmes that address LGBT rights, for example UNESCO funds a large-scale programme which reduces homophobic bullying in schools. However, there are other development agencies which make little or no mention of LGBT issues in the official documents but support LGBT-related work through a rights-based approach. In this situation, LGBT rights are not viewed as an outcome but are incorporated into a process which ensures that international aid leaves no one behind. For example, the Danish International Development Agency (DANIDA) incorporates LGBT issues into a wider perspective on gender equality and social justice. In general, there is a gap between the commitment to LGBT rights and the programme funding for it among most international development agencies. Good practice guides and toolkits are emerging.

The following obstacles for furthering programmes targeting LGBT rights were identified:

- The LGBT acronym conflates issues in an unhelpful way for programming staff. It undermines the diversity between the groups that are broadly identified as LGBT and leads to a "one size fits all" approach to development programming.

- Donor agency staff have limited knowledge of the deeper issues relating to sexual orientation and gender identity and are not always able to integrate these issues into programmes relating to education, agriculture or social protection. In addition, there is homophobia at all levels among agency staff who are hostile to the LGBT rights agenda and unwilling to engage with issues. Better policies and training for staff may address such prejudice.

- There is inadequate data and indicators for assessing the impact of discrimination on LGBT individuals. Such data gaps make it difficult to incorporate LGBT rights into programme design. Moreover, concerns about tackling controversial issues may deter international development agency staff from engaging with these issues.

- $\quad$ LGBT rights are still not fully recognised as a development priority.

\section{United Nations. (2019). The role of the United Nations in Combating Discrimination and Violence Against Lesbian, Gay, Bisexual, Transgender And Intersex People: The Programmatic Overview. United Nations.}

https://www.ohchr.org/Documents/Issues/Discrimination/LGBT/UN_LGBTI_Summary.pdf

This document provides an overview of the work done by United Nations agencies to address discrimination and violence based on sexual orientation, gender identity, sex characteristics and other issues to support the rights of LGBTI communities across the world. Overall, the UN is mainly involved in statements and processes that articulate the rights of LGBTI persons. The UN is also involved in intergovernmental processes and dialogues to discuss these issues under the broad umbrella of human rights. The UN Free and Equal Campaign was a global public information campaign to promote awareness of the rights of LGBTI persons. It received high- 
level support from the Secretary General and included almost 30 countries around the world. Like other development agencies, the United Nations Office on Drugs and Crime (UNODC) addresses LGBTI issues through its HIV prevention and treatment programmes, especially in prisons.

The United Nations Development Programme (UNDP) has partnered with other development actors to produce reports on the status of LGBTI communities in many regions. UNDP has also facilitated cross regional dialogue on sexual orientation and gender identity with other human rights bodies. The United Nations Children's Fund (UNICEF) refers to positive gender socialisation in its Strategic Plan (2018 - 2021) and its Gender Action Plan (2018-2021). LGBTI concerns are addressed in the End Adolescent AIDS programme launched in 2015. The United Nations Educational, Scientific and Cultural Organisation (UNESCO) is mainstreaming issues related to homophobic and trans-phobic violence in its general programmes on school violence and bullying. In 2017 an International Symposium on School Violence and Bullying was held in Seoul, South Korea which included sessions on violence based on sexual orientation and gender identity. A Global Status Report on School Violence that was published after the symposium included a section on sexual orientation and gender identity.

The document does not mention any particular programmes that directly address discrimination towards LGBTI persons.

\section{Ayoub, P. H. (2015). Contested Norms in New Adopter States: International Determinants} Of LGBT Rights Legislation. European Journal of International relations. Vol 21(2). 293 322. https://journals.sagepub.com/doi/full/10.1177/1354066114543335

This article compares the adoption of LGBT rights legislation across EU member states between 1970 and 2009. It argues that the new adopter states were more dependent on international resources for making new issues visible and were more inclined to see policy adoption as a means to gain external legitimacy and improve their reputation.

There is diversity within the European Union countries with respect to LGBT rights. For example, Denmark is a world leading advocate for LGBT rights whereas homosexuality was only decriminalised in Romania in 2001. The study found that among states which were recent adopters of LGBT rights, access to transnational resources was more important. For example, in Poland there was little discourse around LGBT issues. The government was extremely antiLGBT at the time of accession to the European Union. External funding and other support enabled LGBT organisations in Poland to organise marches and campaigns to enhance the visibility of their cause. International support also provides a tangible legitimacy for the LGBT issues on the ground.

\section{Seckinelgin, H. (2018). Same Sex Lives between the Language Of International LGBT} Rights, International Aid and Anti-Homosexuality. Global Social Policy. 48 (2). ISSN 1468 0181. http://eprints.Ise.ac.uk/89703/1/Seckinelgin_Same-sex-lives_Accepted.pdf

This article considers the role of LGBT rights as a condition for international development aid in Africa. It focuses on the language used in policy debates on international LGBT rights and argues that the language creates meanings and categories. Around 2010 the trial and conviction of two homosexual men in Malawi, an anti-homosexuality bill in the Ugandan Parliament and acts 
of violence against LGBT people in Senegal, Cameroon and South Africa provoked strong censure from international community, particularly in public statements made by Hillary Clinton, Barack Obama and Ban Ki Moon. Later at the Commonwealth Heads of Government in Perth, Australia the British Prime Minister, David Cameron, suggested that LGBT rights might become a prerequisite for countries to receive UK aid. Such a position poses many challenges for the United Kingdom's relationship with many African countries. The United States appeared to be a moving in a similar direction based on the statements of Hillary Clinton. Ban Ki Moon was able to negotiate for the release of the men in Malawi during his visit to the country.

In 2013 USAID announced a new initiative under the title of "A New LGBT Global Development Partnership". The UK Department for International Development was trying to engage African governments on the issue of LGBT rights. In response African governments such as Uganda publicly asserted their sovereignty. African presidents rejected the notion that they should decriminalise homosexuality. However, the language used in this debate creates categories which restrict the context within which African activists with diverse sexual orientation and gender identities can be vocal. There is too much focus on legal recognition and change rather than the social change which is a necessary prerequisite for supporting legal developments. Moreover, the priorities of local LGBT organisations and activists should be given due consideration by international actors.

\section{OutRight Action International (2020). The Impact of the COVID-19 Pandemic on LGBTIQ People.}

https://outrightinternational.org/sites/default/files/COVIDsReportDesign_FINAL_LR_0.pdf

The Covid-19 pandemic has exposed the structural and systemic issues disproportionately affecting marginalized populations, including LGBTIQ people, and other vulnerable groups. In response to the severe impact of COVID-19 on LGBTIQ communities around the world, the Partnership for Global LGBTI Equality (PGLE), a collaborative initiative of BSR (Business for Social Responsibility) in partnership with the World Economic Forum (WEF) and UN Human Rights, along with OutRight Action International, launched the COVID-19 Global LGBTIQ Emergency Fund. ${ }^{1}$

Established by OutRight Action International, with support from founding partner Microsoft, the Fund supports LGBTIQ organizations and groups on the frontlines of the pandemic in the global South, addressing a range of humanitarian needs such as emergency food and/or shelter, access to safe and competent healthcare, safety and security, and financial stability. ${ }^{2}$

Such action to support the LGBTIQ community is in line with the principles outlined in the UN Standards of Conduct for Business Tackling Discrimination Against LGBTI People (the UN Standards), which established the framework for PGLE's activities.

\footnotetext{
${ }_{1}^{1}$ See https://www.global-lgbti.org/news-updates/lgbtiq-people-have-been-hit-hard-by-covid-19-heres-how-wecan-provide-support

${ }^{2}$ See https://www.global-lgbti.org/news-updates/lgbtiq-people-have-been-hit-hard-by-covid-19-heres-how-wecan-provide-support
} 


\section{Human Rights Council (2020). Report of the Independent Expert on Protection Against Violence and Discrimination Based on Sexual Orientation and Gender Identity. https://undocs.org/A/HRC/44/53/Add.1}

The Independent Expert on protection against violence and discrimination based on sexual orientation and gender identity conducted an official visit to Ukraine from 30 April to 10 May 2019 to assess the situation of lesbian, gay, bisexual, trans and gender diverse persons in the country.

The Independent Expert observed that activities of civil society's progressive engagement with the business sector to help enhance and foster inclusiveness in the workplace for the LGBTI employees. Further, since 2013, a coalition of civil society organizations created the Ukrainian Corporate Equality Index. The Index is a national survey of corporate policies, rules and practices of private companies to prohibit discrimination at the workplace and support the principle of equality and respect for diversity of employees based on sex, disability, sexual orientation and gender identity.

According to the Independent Expert, such initiatives, will play a critical role in enhancing inclusion of lesbian, gay, bisexual, trans and gender diverse persons in the workplace. ${ }^{3}$

The UN Human Rights Office has developed a toolkit to help activists engage with the private sector. In July 2019, a meeting of business representatives and LGBTI civil society was held in Berlin. The activists were drawn from Australia, China, Costa Rica, India, Iraq, Germany, South Africa, Italy, Czech Republic, The Netherlands, Singapore, Thailand, Israel, Spain, Brazil, Italy, Ukraine, Kenya, Morocco, Uganda, Vietnam, Serbia, United Kingdom and the United States of America, and 25 representatives from the private sector partners. ${ }^{4}$

The participants of the conference came up with a publication titled "Minding the corporate gap: how activists \& companies can work together to tackle LGBTI discrimination." This publication outlined the lessons from the consultative process between the LGBTIQ and the private sector partners.

\section{United Nations. (2019). UN Free \& Equal Campaign Progress Report. https://www.unfe.org/wp-content/uploads/2020/04/UNFE-Report-2019.pdf.}

The UN Human Rights Office has been promoting the UN Free \& Equal campaign videos and materials in the media and at major national events. In countries like Cambodia, the Human Rights Office has supported civil society partners in carrying out activities promoting LGBT equality in the provinces and rural areas.

In Serbia, Free \& Equal Serbia ran an awareness campaign on social media on the effects of LGBT bullying in schools. The UN team has also commissioned a study on LGBT bullying in high

\footnotetext{
${ }^{3}$ See the Report of the Independent Expert on protection against violence and discrimination based on sexual orientation and gender identity on his visit to Ukraine. Available at https://undocs.org/A/HRC/44/53/Add.1.

${ }^{4}$ UN Free \& Equal Campaign Progress Report (2019), page 58. Available at https://www.unfe.org/wpcontent/uploads/2020/04/UNFE-Report-2019.pdf
} 
schools in Serbia. The campaign which was implemented with Labris, a civil society organization that seeks to come up with policy recommendation for the education sector in Serbia. ${ }^{5}$

\section{Acknowledgements}

We thank the following experts who voluntarily provided suggestions for relevant literature or other advice to the author to support the preparation of this report. The content of the report does not necessarily reflect the opinions of any of the experts consulted.

- Rebecca Gordon, University of Birmingham

- Luke Kelly, University of Manchester

- Brigitte Rohwerder, Institute of Development Studies, Brighton

- Jonathan Fisher, University of Birmingham

\section{Key websites}

- Men Against Aids Youth Group in Kenya: https:maaygo.org.

\section{Suggested citation}

Ismail, Z. \& Lesinko, T. (2021). Interventions to Address Discrimination Against LGBTQi Persons. K4D Helpdesk Report. Brighton, UK: Institute of Development Studies. DOI: 10.19088/K4D.2021.104

\section{About this report}

This report is based on six days of desk-based research. The K4D research helpdesk provides rapid syntheses of a selection of recent relevant literature and international expert thinking in response to specific questions relating to international development. For any enquiries, contact helpdesk@k4d.info.

K4D services are provided by a consortium of leading organisations working in international development, led by the Institute of Development Studies (IDS), with Education Development Trust, Itad, University of Leeds Nuffield Centre for International Health and Development, Liverpool School of Tropical Medicine (LSTM), University of Birmingham International Development Department (IDD) and the University of Manchester Humanitarian and Conflict Response Institute (HCRI).

This report was prepared for the UK Government's Foreign, Commonwealth and Development Office (FCDO) and its partners in support of pro-poor programmes. Except where otherwise stated, it is licensed for non-commercial purposes under the terms of the Open Government Licence v3.0. K4D cannot be held responsible for errors, omissions or any consequences arising from the use of information contained in this report. Any views and opinions expressed do not necessarily reflect those of FCDO, K4D or any other contributing organisation.

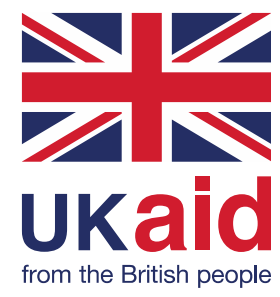

(C) Crown copyright 2021.

\footnotetext{
${ }^{5}$ See .https://outrightinternational.org/sites/default/files/COVIDsReportDesign_FINAL_LR_0.pdf
} 